\title{
Impaired Vitamin D Metabolism with Aging in Women \\ Possible Role in Pathogenesis of Senile Osteoporosis
}

Keh-Sung Tsai, Hunter Heath III, Rajiv Kumar, and B. Lawrence Riggs

Endocrine Research Unit, Division of Endocrinology and Metabolism, and Department of Internal Medicine, Mayo Clinic and Mayo Foundation, Rochester, Minnesota 55905

bstract. Calcium absorption decreases with aging, particularly after age $70 \mathrm{yr}$. We investigated the possibility that this was due to abnormal vitamin $\mathrm{D}$ metabolism by studying 10 normal premenopausal women (group A), 8 normal postmenopausal women within 20 yr of menopause (group B), 10 normal elderly women (group C), and 8 elderly women with hip fracture (group D) whose ages (mean \pm SD) were $37 \pm 4,61 \pm 6,78 \pm 4$, and $78 \pm 4 \mathrm{yr}$, respectively. For all subjects, serum 25 -hydroxyvitamin $\mathrm{D}[25(\mathrm{OH}) \mathrm{D}]$ did not decrease with age, but serum 1,25-dihydroxyvitamin $\mathrm{D}\left[1,25(\mathrm{OH})_{2} \mathrm{D}\right]$, the physiologically active vitamin D metabolite, was lower $(P$ $=0.01$ ) in the elderly (groups $C$ and $D ; 20 \pm 3 \mathrm{pg} / \mathrm{ml}$ ) than in the nonelderly (groups $A$ and $B ; 35 \pm 4 \mathrm{pg} / \mathrm{ml}$ ). The increase of serum 1,25(OH)D after a 24-h infusion of bovine parathyroid hormone fragment 1-34, a tropic agent for the enzyme $25(\mathrm{OH}) \mathrm{D} 1 \alpha$-hydroxylase, correlated inversely with age $(r=-0.58 ; P<0.001)$ and directly with glomerular filtration rate $(r=0.64 ; P<0.001)$. The response was more blunted $(P=0.01)$ in elderly patients with hip fracture $(13 \pm 3 \mathrm{pg} / \mathrm{ml})$ than in elderly controls $(25 \pm 3 \mathrm{pg} / \mathrm{ml})$. We conclude that an impaired ability of the aging kidney to synthesize $1,25(\mathrm{OH})_{2} \mathrm{D}$ could contribute to the pathogenesis of senile osteoporosis.

\section{Introduction}

Everyone loses bone with aging, and women lose more than men $(1,2)$. This decrease in bone mass is associated with an age-related increase in parathyroid function (3-5). In women,

Received for publication 12 December 1983 and in revised form 23 January 1984.

J. Clin. Invest.

(c) The American Society for Clinical Investigation, Inc. $0021-9738 / 84 / 06 / 1668 / 05 \quad \$ 1.00$

Volume 73, June 1984, 1668-1672 increases in serum immunoreactive parathyroid hormone (iPTH) ${ }^{1}$ and in bone turnover (assessed by measurement of serum bone Gla-protein and other biochemical markers [6]) are correlated. Aging is also associated with a decrease in intestinal calcium absorption that is large enough to account for the observed increase in parathyroid function (7-9). Thus, a better understanding of the cause of the decreased calcium absorption could lead to a better understanding of the mechanism of agerelated bone loss.

The vitamin D-endocrine system is the most important regulator of intestinal calcium absorption. Vitamin D undergoes sequential hydroxylation at $\mathrm{C}-25$ in the liver and at $\mathrm{C}-1$ in the kidney to produce 1,25 -dihydroxyvitamin $\mathrm{D}\left[1,25(\mathrm{OH})_{2} \mathrm{D}\right]$, a major, physiologically active form of the vitamin (10). We undertook the present study to determine if elderly women have impaired metabolism of 25-hydroxyvitamin $\mathrm{D}$ [25(OH)D] to $1,25(\mathrm{OH})_{2} \mathrm{D}$ and, if so, whether the defect is more severe in elderly women with hip fractures. Thus, we indirectly evaluated the function of the enzyme $25(\mathrm{OH}) \mathrm{D} 1 \alpha$-hydroxylase by measuring the increase in serum $1,25(\mathrm{OH})_{2} \mathrm{D}$ concentration after infusion of parathyroid hormone (PTH).

\section{Methods}

Subjects and experimental protocol. We studied four groups of women: group A, 10 normal premenopausal women, age, $37 \pm 4$ yr (mean $\pm S D$ ); group B, 8 normal women within $20 \mathrm{yr}$ of menopause, $61 \pm 6 \mathrm{yr}$; group C, 10 normal elderly women, $78 \pm 4 \mathrm{yr}$; and group D, 8 elderly women with fracture of the proximal femur, $78 \pm 4$ yr. None of the normal subjects had a history of nontraumatic fractures, and everyone older than 50 had roentgenograms of the spinal column that showed no vertebral fractures, and bone mineral density values of the lumbar spine (by dual photon absorptiometry) that were within the age-adjusted normal range. In group $D$, the hip fracture had occurred more than 6 mo before the study and resulted from a fall from a position no higher than standing.

1. Abbreviations used in this paper: $1,25(\mathrm{OH})_{2} \mathrm{D}, 1,25$ dihydroxyvitamin $\mathrm{D} ; 25(\mathrm{OH}) \mathrm{D}, 25$-hydroxyvitamin D; bPTH, bovine parathyroid hormone; bPTH(1-34), bovine parathyroid hormone fragment 1-34; GFR, glomerular filtration rate; iPTH, immunoreactive parathyroid hormone; PTH, parathyroid hormone. 
All subjects were ambulatory and none was receiving drugs or had a recognizable medical disease known to affect bone or calcium metabolism. All subjects gave their informed consent, and the experimental protocol was approved by the Mayo Human Studies Committee.

The studies were conducted on a metabolic ward. Fasting blood samples were drawn before and after a 24-h continuous infusion with the synthetic bovine parathyroid hormone fragment 1-34 [bPTH(1-34)]. A 24-h urine collection was made the day before and during the infusion. 7,000 U/mg synthetic bPTH(1-34) (Beckman Instruments, Inc., Spinco Div., Palo Alto, CA) was dissolved in $10 \mathrm{ml}$ of $0.1 \mathrm{M}$ acetic acid containing $1 \%$ human serum albumin (United States Pharmacopeia) $1 \mathrm{~d}$ before the infusion, sterilized by filtration through a filter (Millex-GV; Millipore Corp., Bedford, MA), and stored under sterile conditions at $-70^{\circ} \mathrm{C}$. Immediately before the infusion, it was thawed and transferred to a plastic intravenous bag that contained $208 \mathrm{ml}$ of $1 \%$ human serum albumin in $0.9 \% \mathrm{NaCl}$. After a conjunctival allergy test gave a negative result, bPTH(1-34) was infused at a dosage of $800 \mathrm{U} / 60 \mathrm{~kg}$ body wt (intravenous pump and plastic indwelling catheter, Travenol Laboratories, Inc., Baxter Travenol Laboratories, Deerfield, IL) at the rate of 8 $\mathrm{ml} / \mathrm{h}$ for $24 \mathrm{~h}(55 \mathrm{U} / \mathrm{kg}$ body wt per $\mathrm{h})$. The loss of hormone during filtration and infusion (as estimated by renal membrane adenylate cyclase bioassay) was $<5 \%$.

Laboratory methods. Serum calcium was measured by atomic absorption spectrophotometry before and after the infusion. Serum creatinine and phosphorus were measured by standard AutoAnalyzer methods (Technicon Instruments Corp., Tarrytown, NY). Serum alkaline phosphatase was measured spectrophotometrically in duplicate with $p$ nitrophenyl phosphate (Sigma Chemical Co., St. Louis, MO) as substrate. Serum iPTH was measured by a modification (4) of the method of Arnaud et al. (11). This radioimmunoassay incorporated GP-1M, an antiserum that reacts primarily with determinants in the 44-68 region of the PTH molecule, which is particularly sensitive to increased PTH secretion (4). Glomerular filtration rate (GFR) was calculated from 24-h creatinine clearance corrected to a body surface area of $1.73 \mathrm{~m}^{2}$.
Urinary cyclic AMP (cAMP) in a 24-h urine sample was measured with a radioimmunoassay kit (Becton, Dickinson and Co., East Rutherford, NJ). Results were expressed in terms of GFR. Serum 25(OH)D was determined by the method of Eisman et al. (12); serum $1,25(\mathrm{OH})_{2} \mathrm{D}$ was determined by a modification of the method of Eisman et al. (13) as described by Kumar et al. (14). $5 \mathrm{ml}$ of fasting serum stored at $-70^{\circ} \mathrm{C}$ was used for determination of both $25(\mathrm{OH}) \mathrm{D}$ and $1,25(\mathrm{OH})_{2} \mathrm{D}$. The mean recovery was $82 \%$ for $25(\mathrm{OH}) \mathrm{D}$ and $70 \%$ for $1,25(\mathrm{OH})_{2} \mathrm{D}$. The intraassay variation was $6.7 \%$ for $25(\mathrm{OH}) \mathrm{D}$ and $10 \%$ for $1,25(\mathrm{OH})_{2} \mathrm{D}$.

Statistical analysis. The relationship of variables with age or GFR was assessed by linear regression analysis. Multiple regression analysis including partial correlation coefficients was used to determine the association of variables with age after holding GFR constant and vice versa. A Clinfo software package was used for these analyses. The analysis of covariance, with age and GFR as covariates, was used to compare the four groups. The two-tailed $t$ test for independent samples was used to compare parameters in different groups after the analysis of variance demonstrated the presence of differences among groups. A canonical correlation analysis (15) was used to assess the linear relationship of age and GFR, taken as one set, and the remaining variables, taken as the other set. The SAS software package (SAS Institute, Inc., Raleigh, NC) (16) was used to perform these latter analyses.

\section{Results}

Values for laboratory measurements are given in Table I and their statistical significance is shown in Table II. Compared with the younger women (groups A and B), the elderly women had lower values for GFR, basal serum $1,25(\mathrm{OH})_{2} \mathrm{D}$, and incremental increase in serum $1,25(\mathrm{OH})_{2} \mathrm{D}$ after bPTH(1-34) infusion. The elderly women with hip fracture (group D) had lower values for the incremental increase in serum $1,25(\mathrm{OH})_{2} \mathrm{D}$ than did the elderly normal women. This difference remained significant $(P$

Table I. GFR and Serum Values in Different Groups of Women

\begin{tabular}{|c|c|c|c|c|c|c|}
\hline & A & B & C & $\mathrm{D}$ & $A+B$ & $C+D$ \\
\hline GFR $\left(\mathrm{ml} / \mathrm{min}\right.$ per $\left.1.73 \mathrm{~m}^{2}\right)$ & $93 \pm 3$ & $72 \pm 6$ & $54 \pm 6$ & $44 \pm 5$ & $84 \pm 4$ & $65 \pm 3$ \\
\hline \multicolumn{7}{|l|}{ Serum values } \\
\hline Calcium $(m g / d l)$ & $9.2 \pm 0.1$ & $9.6 \pm 0.1$ & $9.4 \pm 0.1$ & $9.4 \pm 0.1$ & $9.4 \pm 0.1$ & $9.4 \pm 0.1$ \\
\hline \multicolumn{7}{|l|}{ Phosphorus $(m g / d l)$} \\
\hline Basal & $3.4 \pm 0.1$ & $3.6 \pm 0.1$ & $3.7 \pm 0.1$ & $3.6 \pm 0.2$ & $3.5 \pm 0.2$ & $3.7 \pm 0.2$ \\
\hline Incremental* & $-0.7 \pm 0.1$ & $-0.5 \pm 0.2$ & $-0.7 \pm 0.1$ & $-0.6 \pm 0.1$ & $-0.7 \pm 0.1$ & $-0.7 \pm 0.1$ \\
\hline Alkaline phosphatase $(U /$ liter $)$ & $21 \pm 3$ & $27 \pm 2$ & $29 \pm 2$ & $25 \pm 2$ & $23 \pm 2$ & $27 \pm 2$ \\
\hline $\mathrm{iPTH}(\mu l e q / m l)$ & $25 \pm 2$ & $25 \pm 2$ & $31 \pm 3$ & $37 \pm 4$ & $25 \pm 2$ & $33 \pm 3$ \\
\hline $25(\mathrm{OH}) \mathrm{D}(\mathrm{ng} / \mathrm{ml})$ & $45 \pm 4$ & $41 \pm 2$ & $40 \pm 4$ & $40 \pm 2$ & $43 \pm 3$ & $40 \pm 2$ \\
\hline \multicolumn{7}{|l|}{$1,25(\mathrm{OH})_{2} \mathrm{D}(\mathrm{pg} / \mathrm{ml})$} \\
\hline Basal & $37 \pm 7$ & $34 \pm 5$ & $20 \pm 6$ & $21 \pm 3$ & $35 \pm 4$ & $20 \pm 3$ \\
\hline Incremental* & $64 \pm 13$ & $40 \pm 11$ & $25 \pm 3$ & $13 \pm 3$ & $54 \pm 9$ & $20 \pm 2$ \\
\hline \multicolumn{7}{|l|}{ Urine cAMP $(n M / 100 \mathrm{ml} G F R)$} \\
\hline Basal & $3.1 \pm 0.7$ & $3.4 \pm 0.3$ & $3.7 \pm 0.3$ & $4.8 \pm 0.3$ & $3.2 \pm 0.2$ & $4.1 \pm 0.3$ \\
\hline Incremental* & $2.9 \pm 0.4$ & $3.5 \pm 0.4$ & $4.4 \pm 0.6$ & $3.7 \pm 1.0$ & $3.2 \pm 0.3$ & $4.1 \pm 0.6$ \\
\hline
\end{tabular}

* Difference between levels at beginning and end of bPTH(1-34) infusion. Results are shown as mean \pm SE. See Table II for probability values. 
Table II. Probability Values for Comparisons of Data in Table I

\begin{tabular}{|c|c|c|c|c|c|c|}
\hline & A vs. B & A vs. C & $A+B$ vs. $C$ & A + B vs. D & $A+B$ vs. $C+D$ & C vs. D \\
\hline GFR & $<0.05$ & $<0.001$ & $<0.001$ & $<0.001$ & $<0.001$ & NS \\
\hline \multicolumn{7}{|l|}{ Serum values } \\
\hline \multicolumn{7}{|l|}{ Calcium } \\
\hline Basal & $<0.05$ & NS & NS & NS & NS & NS \\
\hline Incremental* & NS & NS & $<0.01$ & $<0.05$ & $<0.05$ & NS \\
\hline \multicolumn{7}{|l|}{ Phosphorus } \\
\hline Basal & NS & NS & NS & NS & NS & NS \\
\hline Incremental & NS & NS & NS & NS & NS & NS \\
\hline Alkaline phosphatase & NS & $<0.05$ & NS & NS & NS & NS \\
\hline iPTH & NS & NS & NS & $<0.01$ & $<0.01$ & NS \\
\hline $25(\mathrm{OH}) \mathrm{D}$ & NS & NS & NS & NS & NS & NS \\
\hline \multicolumn{7}{|l|}{$1,25(\mathrm{OH})_{2} \mathrm{D}$} \\
\hline Basal & NS & NS & $<0.05$ & $<0.01$ & 0.01 & NS \\
\hline Incremental* & NS & $<0.05$ & $<0.01$ & $<0.001$ & $<0.01$ & 0.01 \\
\hline \multicolumn{7}{|l|}{ Urine cAMP } \\
\hline Basal & NS & NS & NS & $<0.001$ & $<0.01$ & $<0.05$ \\
\hline Incremental* & NS & NS & NS & NS & NS & NS \\
\hline
\end{tabular}

* Difference between levels at beginning and end of bPTH(1-34) infusion. Analysis was by unpaired $t$ test; all analyses were two tailed. NS, not significant.

$=0.01$ ) after adjustment by analysis of covariance for GFR alone, age alone, and both together. Urinary cAMP doubled during bPTH(1-34) infusion. The incremental increase was similar in all groups. Serum phosphorus did not change significantly during bPTH(1-34) infusion.

Results of linear regression analyses are given in Table III. When all subjects were considered, with increasing age there was a decrease in GFR and basal serum $1,25(\mathrm{OH})_{2} \mathrm{D}$, an increase in the natural logarithm of serum $\mathrm{PPTH}$, and no change in serum $25(\mathrm{OH}) \mathrm{D}$. The increase in serum $1,25(\mathrm{OH})_{2} \mathrm{D}$ after bPTH(1-34) infusion correlated inversely with age (Fig. 1). It correlated directly with GFR (Fig. 2), and responses were poorest in subjects who had values for GFR $<60 \mathrm{ml} / \mathrm{min}$ per $1.73 \mathrm{~m}^{2}$. With multiple linear regression analysis (Table IV), when age was held constant, the incremental increase in serum $1,25(\mathrm{OH})_{2} \mathrm{D}$ after bPTH(1-34) infusion still correlated marginally with GFR, but when GFR was held constant the correlation with age was lost. For the merged groups, there was an inverse correlation between the incremental increase in serum $1,25(\mathrm{OH})_{2} \mathrm{D}$ and the natural logarithm of basal serum iPTH.

When both age and GFR were considered simultaneously, the canonical correlation analysis showed a significant $(P$ $<0.001$ ) association with the remaining dependent variables. The linear relationship between the dependent variables and age after holding GFR constant was below the level of significance $(P=0.1)$, as was that for GFR after holding age constant $(P$ $=0.08$ ). Thus, both age and GFR may have contributed to the relationship.

\section{Discussion}

Our findings suggest that elderly women have abnormal vitamin D metabolism. The normal levels for serum $25(\mathrm{OH}) \mathrm{D}$ in all

Table III. Correlation Coefficients for Linear Regression of Variables

\begin{tabular}{|c|c|c|c|c|}
\hline \multirow[b]{2}{*}{ Comparison } & \multicolumn{2}{|c|}{ All normal subjects } & \multicolumn{2}{|c|}{ All subjects } \\
\hline & $r$ & $P$ & $r$ & $P$ \\
\hline GFR vs. age & -0.79 & $<0.001$ & -0.82 & $<0.001$ \\
\hline Ln serum iPTH vs. age & 0.34 & NS & 0.44 & $<0.01$ \\
\hline Serum $25(\mathrm{OH}) \mathrm{D}$ vs. age & 0.04 & NS & -0.19 & NS \\
\hline \multicolumn{5}{|l|}{ Basal serum $1,25(\mathrm{OH})_{2} \mathrm{D}$} \\
\hline vs. age & -0.33 & NS & -0.34 & $<0.05$ \\
\hline vs. GFR & 0.32 & NS & 0.36 & $<0.05$ \\
\hline vs. In serum iPTH & -0.35 & NS & -0.37 & $<0.05$ \\
\hline \multicolumn{5}{|l|}{$\begin{array}{l}\text { Incremental serum } \\
\qquad 1,25(\mathrm{OH})_{2} \mathrm{D}^{*}\end{array}$} \\
\hline vs. age & -0.48 & $<0.01$ & -0.58 & $<0.001$ \\
\hline vs. GFR & 0.57 & $<0.001$ & 0.64 & $<0.001$ \\
\hline vs. In serum iPTH & -0.23 & NS & -0.33 & NS \\
\hline
\end{tabular}

* Difference between levels at beginning and end of bPTH(1-34) infusion. NS, not significant. 


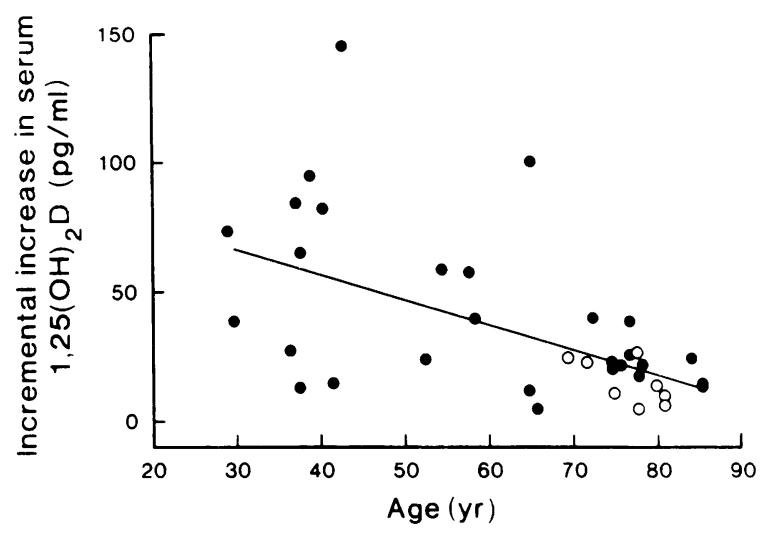

Figure 1. Relationship between incremental increase in serum $1,25(\mathrm{OH})_{2} \mathrm{D}$ after bPTH(1-34) infusion and age in normal subjects $(\bullet)$ and in patients with hip fracture $(0)$.

groups indicate nutritional adequacy for vitamin $\mathrm{D}$, but the decrease in serum $1,25(\mathrm{OH})_{2} \mathrm{D}$ in the elderly women to levels of almost half of those found in younger women suggests impaired metabolism of $25(\mathrm{OH}) \mathrm{D}$ to $1,25(\mathrm{OH})_{2} \mathrm{D}$. This confirms earlier reports by our group (17) and by Manolagas et al. (18). Because serum $1,25(\mathrm{OH})_{2} \mathrm{D}$ and calcium absorption are directly correlated in normal subjects (17), the decrease in circulating levels of $1,25(\mathrm{OH})_{2} \mathrm{D}$ in the elderly may account for their decrease in calcium absorption. The alternative possibility, a primary decrease in transmucosal intestinal calcium transport, seems unlikely: This would result in a compensatory increase in serum levels of $1,25(\mathrm{OH})_{2} \mathrm{D}$, and a decrease was observed. The possibility of a dual defect involving both kidney and gut, however, cannot be excluded by our data. Moreover, the significant inverse correlation between serum $1,25(\mathrm{OH})_{2} \mathrm{D}$ and serum iPTH in our study is consistent with the possibility that a decrease in circulating levels of $1,25(\mathrm{OH})_{2} \mathrm{D}$ contributes to the well-documented (3-5) increase in parathyroid function in the elderly.

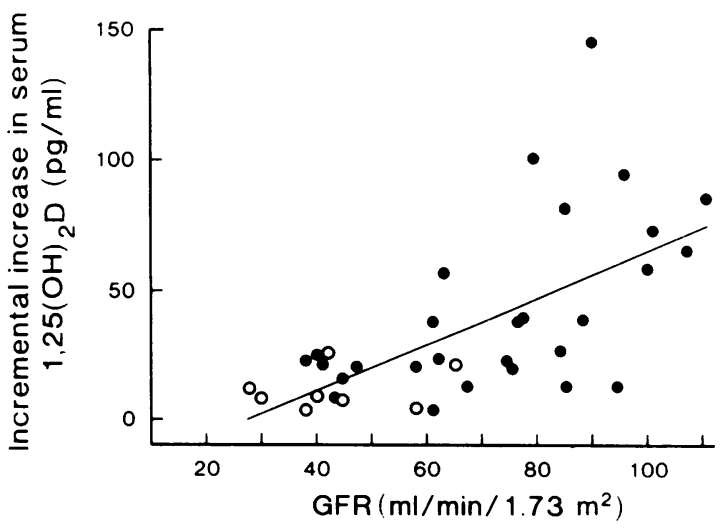

Figure 2. Relationship between incremental increase in serum $1,25(\mathrm{OH})_{2} \mathrm{D}$ after bPTH(1-34) infusion and GFR in normal subjects $(\bullet)$ and in patients with hip fracture (O)
Table IV. Partial Correlation Coefficients for Incremental Increase in Serum 1,25(OH) ${ }_{2} \mathrm{D}$ [After bPTH(1-34) Infusion], Age, and GFR

\begin{tabular}{|c|c|c|c|c|}
\hline \multirow[b]{2}{*}{ Comparison* } & \multicolumn{2}{|c|}{ All normal subjects } & \multicolumn{2}{|c|}{ All subjects } \\
\hline & $r$ & $P$ & $r$ & $P$ \\
\hline$X Y . Z$ & -0.06 & NS & -0.11 & NS \\
\hline$X Z . Y$ & 0.36 & 0.07 & 0.36 & 0.04 \\
\hline
\end{tabular}

${ }^{*} X=$ incremental increase in serum $1,25(\mathrm{OH})_{2} \mathrm{D} ; Y=$ age; $Z=$ GFR.

NS, not significant.

We studied the mechanism of the age-related decrease in serum levels of $1,25(\mathrm{OH})_{2} \mathrm{D}$ by assessing the effect of exogenous infusion of PTH, a tropic agent for renal 25(OH)D $1 \alpha$-hydroxylase (19). Our findings suggest a primary impairment of enzyme function, as has been reported in aging rats $(20,21)$. Because we did not do $\left[{ }^{3} \mathrm{H}\right] 1,25(\mathrm{OH})_{2} \mathrm{D}_{3}$ kinetic studies, the unlikely possibility that the decreased basal and incremental values for serum $1,25(\mathrm{OH})_{2} \mathrm{D}$ were due to increased metabolic clearance cannot be excluded. Although the incremental increase in serum $1,25(\mathrm{OH})_{2} \mathrm{D}$ after bPTH(1-34) infusion correlated with both age and GFR, partial correlation coefficients suggest that the correlation with GFR was the more important. Thus, the decrease in renal function with age (22) may be an important determinant of this abnormality. The increase in urinary cAMP excretion after bPTH(1-34) infusion in the elderly subjects, however, was equivalent to that of the younger subjects.

Our hypothesis is that the decreased production of $1,25(\mathrm{OH})_{2} \mathrm{D}$ by the aging kidney results in a decrease in intestinal calcium absorption, which in turn causes increased PTH secretion. The PTH then causes increased bone turnover. Because the elderly also have decreased bone formation at the cellular level (23) (less bone is formed than is resorbed at each individual bone remodeling unit), an increase in bone turnover (and, thus, in the activation of new bone remodeling units) would lead to an increase in bone loss. That the impairment in 25(OH)D $1 \alpha$ hydroxylase reserve capacity was more severe in elderly women with hip fractures than in age-matched controls further supports this hypothesis.

Our results apply only to patients with senile osteoporosis and not to patients with postmenopausal osteoporosis; there is growing evidence that these are distinct syndromes (24). In contrast with the findings reported here, both Riggs et al. (25) and Sorensen et al. (26) found that the increase in serum $1,25(\mathrm{OH})_{2} \mathrm{D}$ after administration of parathyroid extract in women with postmenopausal osteoporosis did not differ from that in age-matched postmenopausal women without osteoporosis. Although serum $1,25(\mathrm{OH})_{2} \mathrm{D}$ levels are decreased in both osteoporosis syndromes (17), the decrease in $25(\mathrm{OH}) \mathrm{D} 1 \alpha$-hydroxylase activity in patients with postmenopausal osteoporosis appears to be secondary to a decrease in PTH secretion as a result of accelerated loss of bone, whereas the reduction in enzyme function in patients 
with senile osteoporosis may be a primary defect that ultimately causes increased parathyroid function. Slovik et al. (27) reported that six normal women and men (mean age, $29 \mathrm{yr}$ ) had a greater increase in serum $1,25(\mathrm{OH})_{2} \mathrm{D}$ after PTH infusion than did five osteoporotic women and men (mean age, $58 \mathrm{yr}$ ) with vertebral fractures. Because their groups were not age-matched, however, this could have been an age effect.

Senile osteoporosis traditionally has been attributed to bone cell senescence and, thus, has been considered not to be amenable to therapy. We have documented a potentially treatable (28) abnormality of vitamin D metabolism, which could contribute to age-related bone loss. It is now appropriate to determine whether impaired calcium absorption in elderly women can be corrected by treatment with a small dose of $1,25(\mathrm{OH})_{2} \mathrm{D}$ and, if so, whether this reduces their bone loss.

\section{Acknowledgments}

We thank Lynda M. McDowell, Karen Nelson, and Susan L. Bollman for their technical assistance and Dr. A. R. Zinsmeister for his advice and assistance in the statistical analyses.

This work was supported in part by National Institutes of Health grants AM-27065, AM-25409, AM-19607, and RR-00585.

\section{References}

1. Riggs, B. L., H. W. Wahner, W. L. Dunn, R. B. Mazess, K. P. Offord, and L. J. Melton III. 1981. Differential changes in bone mineral density of the appendicular and axial skeleton with aging. Relationship to spinal osteoporosis. J. Clin. Invest. 67:328-335.

2. Mazess, R. B. 1982. On aging bone loss. Clin. Orthop. Relat. Res. 165:239-252.

3. Wiske, P. S., S. Epstein, N. H. Bell, S. F. Queener, J. Edmondson, and C. C. Johnston. 1979. Increases in immunoreactive parathyroid hormone with age. N. Engl. J. Med. 300:1419-1421.

4. Gallagher, J. C., B. L. Riggs, C. M. Jerpbak, and C. D. Arnaud. 1980. The effect of age on serum immunoreactive parathyroid hormone in normal and osteoporotic women. J. Lab. Clin. Med. 95:373-385.

5. Insogna, K. L., A. M. Lewis, B. A. Lipinski, C. Bryant, and D. T. Baran. 1981. Effect of age on serum immunoreactive parathyroid hormone and its biologic effects. J. Clin. Endocrinol. Metab. 53:10721075.

6. Delmas, P. D., D. Stenner, H. W. Wahner, K. G. Mann, and B. L. Riggs. 1983. Increase in serum bone $\gamma$-carboxyglutamic acid protein with aging in women. Implications for the mechanism of age-related bone loss. J. Clin. Invest. 71:1316-1321.

7. Avioli, A. V., J. E. McDonald, and S. W. Lee. 1965. The influence of age on the intestinal absorption of ${ }^{47} \mathrm{Ca}$ absorption in women and its relation to ${ }^{47} \mathrm{Ca}$ absorption in postmenopausal osteoporosis. J. Clin. Invest. 44:1960-1967.

8. Bullamore, J. R., J. C. Gallagher, R. Wilkinson, B. E. C. Nordin, and D. H. Marshall. 1970. Effect of age on calcium absorption. Lancet. II:535-537.

9. Alevizaki, C. C., D. G. Ikkos, and P. Singhelakis. 1973. Progressive decrease of true intestinal calcium absorption with age in normal man. J. Nucl. Med. 14:760-762.

10. DeLuca, H. F. 1983. Metabolism and mechanism of action of vitamin D. 1983. Excerpta Med. Int. Congr. Ser. 1:7-73.
11. Arnaud, C. D., H. S. Tsao, and T. Littledike. 1971. Radioimmunoassay of human parathyroid hormone in serum. J. Clin. Invest. 50:21-34.

12. Eisman, J. A., R. M. Shepard, and H. F. DeLuca. 1977. Determination of 25-hydroxyvitamin $D_{2}$ and 25-hydroxyvitamin $D_{3}$ in human plasma using high-pressure liquid chromatography. Anal. Biochem. 80:298-305.

13. Eisman, J. A., A. J. Hamstra, B. E. Kream, and H. F. DeLuca. 1976. A sensitive, precise, and convenient method for determination of 1,25-dihydroxyvitamin D in human plasma. Arch. Biochem. Biophys. 176:235-243.

14. Kumar, R., W. R. Cohen, P. Silva, and F. H. Epstein. 1979. Elevated 1,25-dihydroxyvitamin D plasma levels in normal human pregnancy and lactation. J. Clin. Invest. 63:342-344.

15. Morrison, D. F. 1967. Multivariate Statistical Methods. McGrawHill Inc, New York. 338 pp.

16. Statistical Analysis System User's Guide. 1979. J. Helwig and K. A. Council, editors. SAS Institute, Inc., Raleigh. 139-142.

17. Gallagher, J. C., B. L. Riggs, J. Eisman, A. Hamstra, S. B. Arnaud, and H. F. DeLuca. 1979. Intestinal calcium absorption and serum vitamin D metabolites in normal subjects and osteoporotic patients. Effect of age and dietary calcium. J. Clin. Invest. 64:729-736.

18. Manolagas, S. C., F. L. Culler, J. E. Howard, A. S. Brickman, and L. J. Deftos. 1983. The cytoreceptor assay for 1,25-dihydroxyvitamin $\mathrm{D}$ and its application to clinical studies. J. Clin. Endocrinol. Metab. 56:751-760.

19. DeLuca, H. F. 1972. Parathyroid hormone as a trophic hormone for 1,25-dihydroxyvitamin $D_{3}$, the metabolically active form of vitamin D. N. Engl. J. Med. 287:250-251.

20. Horst, R. W., H. F. DeLuca, and N. Jorgenson. 1978. The effect of age on calcium absorption and accumulation of $1,25(\mathrm{OH})_{2} \mathrm{D}_{3}$ in intestinal mucosa of rats. Metab. Bone Dis. Relat. Res. 1:29-33.

21. Armbrecht, H. J., T. V. Zenser, and B. B. Davis. 1980. Effect of vitamin D metabolites on intestinal calcium absorption and calciumbinding protein in young and adult rats. Endocrinology. 106:469-475.

22. Davies, D. F., and N. W. Shock. 1950. Age changes in glomerular filtration rate ERPF and tubular excretory capacity in adult males. $J$. Clin. Invest. 29:496-500.

23. Lips, P., P. Courpron, and P. Meunier. 1978. Mean wall thickness of trabecular bone packets in human iliac crest: changes with age. Calcif. Tissue Res. 26:13-17.

24. Riggs, B. L., and L. J. Melton III. 1983. Heterogeneity of involutional oteoporosis: evidence for two distinct osteoporosis syndromes. Am. J. Med. 75:899-901.

25. Riggs, B. L., A. Hamstra, and H. F. DeLuca. 1981. Assessment of 25 -hydroxyvitamin D $1 \alpha$-hydroxylase reserve in postmenopausal osteoporosis by administration of parathyroid extract. J. Clin. Endocrinol. Metab. 53:833-835.

26. Sorensen, O. H., B. Lumholtz, B. Lund, B. Lund, I. L. Hjelmstrand, L. Mosekilde, F. Melsen, J. E. Bishop, and A. W. Norman. 1982. Acute effects of parathyroid hormone on vitamin D metabolism in patients with the bone loss of aging. J. Clin. Endocrinol. Metab. 54:12581261.

27. Slovik, D. M., J. S. Adams, R. M. Neer, M. F. Holick, and J. T. Potts, Jr. 1981. Deficient production of 1,25-dihydroxyvitamin D in elderly osteoporotic patients. N. Engl. J. Med. 305:372-374.

28. Gallagher, J. C., C. M. Jerpbak, W. S. S. Jee, K. A. Johnson, H. F. DeLuca, and B. L. Riggs. 1982. 1,25-dihydroxyvitamin $D_{3}$ : shortand long-term effects on bone and calcium metabolism in patients with postmenopausal osteoporosis. Proc. Natl. Acad. Sci. USA. 79:33253329. 